\title{
POLICE REVIEW BOARDS AND POLICE ACCOUNTABILITY
}

\author{
James R. Hudson*
}

\section{INTRODUCTION}

The problem of accountability of public officials and public agencies is one of the most difficult in democratic theory and practice. ${ }^{1}$ While it is recognized that democratic governments, if they are to accomplish their mandates, must be allocated certain authority, it is equally recognized that the government and its officials can abuse this power. The tensions created by the need to allocate governmental power without eroding governmental responsiveness are manifest in two important respects. On the one hand, abuse of governmental power may jeopardize the individual liberty of a citizen or group of citizens. On the other hand, the possibility that usurpers of power will rule arbitrarily without regard for the will of the governed has concerned citizens and students of American democracy since the days of the founding fathers. ${ }^{2}$

Over the past decade criticism of the procedures and practices of bureaucracies providing municipal services has increased. A number of programs and policies have been recommended and enacted that would help to maintain a balance between governmental bureaucratic power and bureaucratic responsiveness. Among these policies have been the establishment of legal services for the poor, ${ }^{3}$ demands for community control of schools and police," "maximum feasible participation" in poverty programs, ${ }^{5}$ and police review boards. ${ }^{6}$ While the subject of this article is police review boards, it should be clear that the importance of accountability to clients and citizens is not unique to the police. As a report to the President's Commission on Law Enforcement and Administration of Justice put the issue:

Incompetence and mistreatment by housing, sanitation, health and welfare officials can be as injurious to citizens as mistreatment by police and should be equally subject to public scrutiny. These officials, like policemen, are public servants. ${ }^{7}$

- Assistant Professor of Sociology, State University of New York at Stony Brook.

The author prepared the materials on police review boards found in Field Surveys IV, Volume 2, The President's Commission on Law Enforcement and Administration of Justice, I966.

The research upon which this paper is based was supported by the National Institute of Mental Health (Grant \#I RO I MH I4997-OI). Additional funds for clerical assistance were made available under a Grant-in-Aid from the Graduate School of the State University of New York at Stony Brook. The author acknowledges the helpful assistance of Anne M. Hudson in the preparation of this paper.

${ }^{1}$ G. Almond \& S. Verba, The Crvic Culture 34 I (abr. ed. I965).

${ }^{2}$ R. Hofstadter, The axierican Political Tradition 3-r7 (I948).

' Hannon, The Leadership Problem in the Legal Services Program, 4 LAw \& Soc'y Rev. 235 (1969).

A. Altshuler, Conamunity Control, (I970).

- Rubin, Maximum Feasible Participation, 385 Annals I4 (1969).

${ }^{3}$ Report of the National Advisory Commission on Civil Disorders 3ro-r2 (Bantam Books ed. 1968) [hereinafter cited as Crvil Disonders]. This is popularly known as the Kerner Commission Report.

7 The Prestdent's Commisston on Lat Enforcement and Administration of Justice, Task Force Report: The Police 198 (I967) [hereinafter cited as TASK ForCE]. 
Current interest in the accountability of public bureaucracies has been stimulated particularly by the civil rights movement, which challenged the traditional relationship between the public bureaucracy and its citizen-clients. ${ }^{8}$ In the field of social welfare, for example, there has been a distinct movement on the part of clients and client organizations to change their image from that of supplicants to that of rights-bearing citizens. ${ }^{\ominus}$ Clients are no longer willing to accept the traditional relationship as the only possible one. While at one time the client accepted the definition of himself provided by the agency, which usually emphasized his dependency, the new position is that the client is a capable individual who may, indeed, have some knowledge that the agency does not have about his needs and how to meet them. ${ }^{10}$ The redefinition of client-agency relationships is not restricted to social welfare agencies, but is a general prototype for agencies that serve the public.

While the civil rights movement called attention to actual and potential abuse of government authority in certain cases, a concurrent recognition of a tremendous spread in the scope of government power revived concern about mechanisms for insuring retention of sovereignty by the people. Reich, ${ }^{11}$ commenting on the role of government in general, demonstrates that it is in a position to allocate various kinds of wealth. "To the individual, these new forms, such as a profession, job, or right to receive income, are the basis of his various statuses in society, and may therefore be the most meaningful and distinctive wealth he possesses." ${ }^{\text {"12 }}$ Government services at all levels play an increasingly central part in the lives of members of our society. For many, government may be the only source of housing, education, medical services, and income, and thus relations with the agencies that dispense these services become critical for the individual. The elimination of alternative sources of income and services makes the actions of public agencies subject to closer scrutiny than they were when government was more restricted.

The extension of governmental power over the lives of citizens has accelerated at the same time that public bueaucracies have increased their control over governmental policy. This change can be traced in part to efforts to create a professional, nonpartisan civil service. Beginning with the progressive reform movement in the late Igth century, American cities were reorganized to divorce public agencies from potentially corrupting direct political influence. Elaborate civil service regulations and procedures were instituted to insure politically nonpartisan bureaus staffed by career civil servants committed to public service. In the process, both the public and elected officials lost a good deal of the control that they once had over

\footnotetext{
${ }^{8}$ O'Neil, Unconstitutional Conditions, in THE LAw of THE Poor II9 (J. Ten Broek ed. I966); Reich, Midnight Welfare Searches and the Social Security Act, 72 YALE L.J. I347 (1963); Reich, Individual Rights and Social Welfare, 74 YALE L.J. 1245 (1965).

${ }^{\circ} \mathrm{G}$. Steiner, The State of Welfare 280-313 (I97x); O'Neil, sipra note 8.

${ }^{10}$ R. Kramer, Participation of the Poor 6-10 (1969).

11 Reich, The New Property, 73 YALE L.J. 733 (I964).

$127 d$. at 739 .
} 
the operations of public agencies. As a result, Lowi writes: "The modern city is now well run but badly governed because it is now composed of islands of functional power before which the modern mayor stands impoverished."13

As the people and the politicians were losing control over public agencies, the government employees themselves acquired considerable autonomy in the internal operations of their bureaus. Sometimes, but not always, this power was obtained on the basis of technical expertise or professional status. Furthermore, the efforts of public employees to improve their own conditions of employment, to increase their economic security, and to improve or expand services to the public have generated major political issues. These activities have been spearheaded by strong unions and employee associations using many of the traditional strategies of the labor movement including strikes, picketing, petitions, and mass demonstrations. Like other public employees, associations of policemen have been active in shaping events. They have influenced the course of campaigns for police accountability in several cities, including New York and Philadelphia. Their activities were similar to those of hospital workers, welfare workers, teachers, firemen and garbage collectors who, involved with public bureaucracy as both employees and citizens, have been active in many communities.

\section{The Debate Over Police Review Boards}

A number of arguments have been raised about the responsiveness of channels of police accountability other than review boards. The issue is not whether municipal police departments should be in no respect accountable to the community; instead the dispute forms around the question of whether existing accountability measures make a department sufficiently responsive in the absence of a police review board. The extensive published literature on this issue runs the gamut of style from presidential commission reports and academic journals to the popular press and propaganda pamphlets. Those who support the existing system are drawn mainly from the ranks of policemen's mutual aid organizations, police officials, and conservative groups. Their strongest opposition has come from civil rights and civil liberties organizations and from the report of the Kerner Commission.

\section{A. The Crisis Over the Legitimacy of Police Practices}

Those who see a need to redress the balance between power and responsiveness in municipal police departments cite evidence of a general loss of confidence among large segments of the population in police operations and in the effectiveness of departmental procedures for review of police conduct. The Kerner Commission report, in its analysis of the sources of civil disorders, lists among the causes of black hostility toward the police "the almost total lack of effective channels for redress of complaints against police conduct."14

\footnotetext{
${ }^{13}$ T. Lowi, The END of Liberalism 201 (1969).

${ }^{16}$ Civil Disorders at 310.
} 
The police are not perceived as impartial, neutral enforcers of the law, particularly by the citizens of ghetto neighborhoods. Instead of contributing to the solution of problems plaguing society, the police are thought to exacerbate them..$^{15}$ The tensions that exist between the police and some citizens reduce the likelihood that those citizens will be willing to accept current accountability procedures as fair or adequate. Until this lack of confidence is overcome, belief in police responsiveness has been destroyed for many citizens. The generalized lack of confidence is buttressed by experiences with specific police department review systems. Coxe, for example, claims that for sixteen years prior to the creation' of a civilian review board in Philadelphia, "there was to the knowledge of the American Civil Liberties Union, not one instance of the Police Department's disciplining a member of the force because of a wrong done to a civilian, on the complaint of a civilian."16 It is asserted that in some communities police commanders will simply refuse to accept any complaint from ghetto residents. ${ }^{17}$

An obvious alternative channel of redress for citizens who feel that policemen have violated their rights is the appropriate local, state, or federal court. In response, Beral and Sisk contend that the relationship between the police and the district attorney's office is often symbiotic, "and prosecutors may well be reluctant to jeopardize their relations with the police, on whose cooperation they often rely."18 Furthermore, litigation is an expensive and time-consuming process which the nature of the grievance may not warrant.

Although a complaint may not justify court action, to the aggrieved citizen it may seem sufficiently important to require some official settlement. A grievance unresolved remains a constant source of antagonism between the police and the citizen. If the citizen is frustrated in obtaining redress, his anger and hostility are compounded. Advocates speak frequently about the safety-valve component of external review procedures. Pointing out that "a number of aggrieved complainants are not interested in having disciplinary action taken against the offending officer, but merely request an apology and a statement that their rights will be respected in the future," the Fourth Annual Report of the Philadelphia Police Advisory Board concludes that "no longer is it necessary for a citizen who felt himself wronged by police actions to harbor resentment within himself, or to spread his hostile feelings throughout the community."19

In reply to the above claims which question the responsiveness of the police organization to citizens, supporters of existing channels of redress invoke the concept of the professional status of law enforcement officers. Organizations such as

\footnotetext{
${ }^{15} \mathrm{~J}$. Skolnick, The Politics of Protest 24I-92 (1969).

${ }^{10}$ Coxe, Police Advisory Board, 35 Conn. B.J. 138, r40 (rg6r).

${ }^{17}$ Crvil Disorders at 3 Io.

${ }^{18}$ Note, The Administration of Complaints by Civilians Against the Police, 77 Finv. L. Rev. 499, 500 (I964). See also Barton, Civilian Review Boards and the Handling of Complaints Against the Police, 20 U. Tononto L.J. 448, 453 (I970).

${ }^{10}$ [1962] Pa., Philadel.phis Police Advisory Bd. ANs. Rep. 4 [hereinafter cited as ig62 ANn. Rep.].
} 
the International Association of Chiefs of Police (IACP) insist that, as in any profession, discipline of police officers comes properly and most effectively from fellow members of the profession. ${ }^{20}$ Even if professional status is not granted, it may be argued that from an organizational point of view the responsibility for discipline of policemen should be placed within the command structure itself. It is contended that the basis of police accountability to the community should be the procedures of the department since the commander is either elected by the people or appointed by responsible officials. While law enforcement officers concede that they do not always perform according to the standards of their profession or rules of their organizations, they assert that effective remedies for misconduct are available within the departmental structure. If those within the command structure "are held accountable for inexcusable failures to detect and discipline offenders, they can eliminate much of the behavior that now brings police establishments into disrepute."21

Some investigators have concluded that existing internal review and investigation procedures are not necessarily inadequate. A report to the Mayor of Chicago from a citizens' committee to study police-community relations states that the techniques of the Internal Investigation Division of the Chicago Police Department "are adequate to insure that each complaint against a police officer is thoroughly and objectively investigated."22 Nor did this study find any instance where police engaged in efforts to cover up an investigation. 'Indeed, such a 'cover-up' would be unlikely, if not impossible, due to the sophisticated system of checking and cross-checking of the progress of each investigation." 23

The IACP has similarly concluded that procedures short of civilian review boards will provide adequate public accountability. While advocating formal machinery for the investigation of complaints as "an absolute necessity" for every police department, the organization identifies the alternatives available to citizens dissatisfied with the outcome of internal review. ${ }^{24}$ At the local level, elected officials, civil and criminal courts, and the local prosecutors are possible avenues of appeal. The FBI, the Justice Department, and various civil rights commissions are also described as "well-established, competent and authorized institutions of legal redress."25

The supporters of the police organization save their strongest words and most extensive arguments for justifying opposition to civilian-dominated police review boards. The debate over the desirability of review boards to enhance the accountability of the police is the subject of a subsequent section.

\footnotetext{
${ }^{\circ 0}$ V. Leonard \& H. More, Police Organtzation and Management 92 (3d ed. i97I).

${ }^{21}$ Gellhom, Police Review Boards, 9 Colum. F. 5, 7 (1966).

22 Citizens' Commttee to Study Police-Commontry Relations in the City of Chicago, Police AND Puslic 99 (1967).

${ }^{28} I d$.

${ }^{24}$ V. LEONARD \& H. MORE, supra note 20 , at $9 \mathrm{r}$.

${ }^{25}$ Id.
} 


\section{B. Characteristics of Civilian Review Boards}

The organization and operation of civilian review boards are not standardized either in practice or theory. Some common characteristics can, however, be identified in proposals for review mechanisms. For example, it is usually proposed that these organizations be staffed by civilians who will operate outside the jurisdiction of police departments but who are authorized to recommend the disciplining of police officers. It has been suggested that to be effective such organizations must utilize a simple complaint procedure and have a staff adequate to insure prompt and thorough investigations of all complaints. In addition, the organization should allow the complainant to participate in investigations, hearings, or conciliation procedures and notify him of the outcome of the deliberations. ${ }^{28}$

In comparing four civilian review boards that were operating at the time of the study, a report to the President's Commission on Law Enforcement and Administration of Justice noted that these boards "have been advisory only, having no power to decide cases."27 The advice can vary. For example, in Philadelphia and Rochester the advice could include recommendations for disciplinary action, but in New York City and Washington, D.C., the review boards "even lacked the power to indicate their views on the merits of the case, being limited to recommending whether a police trial was necessary or not."28 In the operational details, further variations occurred. Some boards had subpoena power, whereas others did not. Representation by counsel was always allowed, and provision for counsel for indigent complainants was made by three of the four boards. Although only one board opened its hearings to the public, each board had some type of hearing procedure. There were also arrangements by each of these boards for informal methods of settlement. No board had an investigating staff composed of non-police personnel, although in one case an investigating staff was attached to the board. ${ }^{29}$

The composition of review boards is yet another matter. Since the demand for civilian review was stimulated in part by alleged police misconduct against minority group members, the question of the ethnic composition of these boards has been raised. While in neither New York City nor Philadelphia was there an official policy as to the distribution of board membership, the practice was to obtain representation of ethnic minority groups. ${ }^{30}$ Philadelphia always had an academician with a background in criminology or sociology. The question of police representation has been solved in several ways. In New York City, three of the seven members of the board were police personnel; ${ }^{31}$ in other cities former police officers have been appointed.

\footnotetext{
${ }^{26}$ A. Black, The People and the Police 216-25 (1968); Civil Disorders at 3 ro.

27 TASK FORCE at 200.

${ }^{28} \mathrm{Id}$.

${ }^{20} \mathrm{Id}$.

${ }^{80}$ BLACK, supra note 26 , at 80 .

${ }^{31}$ New York, N.Y., Police Dep't, General Orders No. I4, Amendments to the Rules and Procedures, May I7, r966, at 2 [hereinafter cited as General Orders No. 14].
} 


\section{The Case Against Civilian Review}

The opposition of law enforcement officers to police review boards made up of civilians is founded on a basic tenet of their professional standards-that jurisdiction over the discipline of members of a police force belongs exclusively with the command structure. Because review boards tend to interfere with this jurisdiction, it is felt that they undermine the authority of the police command. That the boards in every case known to this investigator have been only advisory with respect to police discipline, and that the power to determine sanctions against an officer remains within his department is disregarded by police supporters. Having to answer to anyone outside the traditional framework of government, such as, grand juries, civil service commissions, or departmental disciplinary bodies, is repugnant to the officers. Opponents of civilian review insist that adherence to the principle of departmental jurisdiction over discipline is necessary to preserve the morale, effectiveness, and efficiency of a law enforcement organization. The public expects the police to act quickly and decisively in critical situations. Willingness to do so depends upon the line officer's belief that, whenever his actions are questioned and reviewed, those who do so must be knowledgeable about police practices. That belief contributes greatly to high morale on the force, and morale is a fundamental component of an effective police organization. ${ }^{\mathbf{2}}$

It is asserted that review boards staffed by laymen will severely threaten morale. As a consequence, police officers will feel restrained from taking necessary and justifiable actions. This contention has received support from the Director of the Federal Bureau of Investigation who, in his report on the 1964 riots in Philadelphia, claimed that the presence of a civilian board in that city "was well known in the community and the rioters was thereby emboldened to resist and completely defy the efforts of the police to restore order. In short, the police were so careful to avoid accusations of improper conduct that they were virtually paralyzed."33 In response, it has been pointed out that a policy of police restraint in order to save lives was consciously undertaken by a number of municipal authorities, including those in Philadelphia. ${ }^{34}$ Furthermore, the many reports following the urban riots of the mid-Ig6o's contain no data to the effect that the severity or duration of the disorder or the nature of official response to it was any different in cities in which there were civilian review boards than in cities in which there were none. ${ }^{35}$

The attack on civilian' review boards often extends to specific objections about procedures and practices. One allegation is that police review boards, while resembling courts of law, do not provide certain vital procedural safeguards. ${ }^{36}$ Civilian review boards do not always observe rules of evidence when hearing a case. The

\footnotetext{
32 Brown, Police Review Boards, yo PoLICE I9 (I966); Moore, Police Review Boards, CaIIfornis PeAce Officer, Nov.-Dec., 1960, at 5.

${ }^{83}$ Philadelphia Inquirer, Sept. 29, 1964 , at $x$.

${ }^{86} \mathrm{ld}$.

${ }^{35}$ M. Janowitz, Soctar Control of Escalated Riots (I968); Civil Disorders at 35-82.

${ }^{80}$ Brown, supra note 32.
} 
boards are "often referred to as being 'kangaroo courts.' This descriptive term has been used because such boards deprive the police officer of his basic constitutionally guaranteed rights, e.g., to face his accuser, representation by counsel, and protection against double jeopardy."37 But it must be recalled that hearings in the four cities mentioned previously were not trials; rather they constituted administrative procedures where the goal was to obtain information on which to base a decision about whether subsequent formal action was warranted. Furthermore, both police officers and complainants might be represented by counsel.

Civilian review boards have been criticized for their willingness to entertain minor complaints. Opponents assert that this results in a waste of time, money, and resources of the police department that could otherwise be spent on the more significant aspects of law enforcement. ${ }^{38}$ It is contended that methods are needed to screen out complaints that are trivial or unfounded.

Finally, it is suggested that the creation of civilian review boards will not contribute to reducing community tensions, as those who support them claim, but instead will be deleterious to police-community relations in general. In a sophisticated argument, Gellhorn maintains that "the review system presupposes a polarization-the complainant (and, behind him, the disadvantaged ethnic minority) on one side, the accused policeman (and behind him the policeman's mutual aid organization) on the other-that almost inescapably makes for extremely burdensome procedures."39 To create symbols of disunity, to encourage polarization can only contribute to the crisis; it does not contribute to a solution. Proponents of the boards, of course, would respond that the polarization is already sharp in many communities and cannot be wished away or ignored; by offering a new channel of reconciliation, civilian complaint review boards may ease strong antagonisms.

\section{II}

\section{The Politics of Civiluan Review in Two Cities}

A comparison of two civilian review boards which received national attention, the New York City Civilian Complaint Review Board (CCRB) and the Philadelphia Police Advisory Board (PAB) will provide concrete examples of the structure and operation of civilian-run boards. Both of these boards were also subjects of political controversies that ultimately led to their abolition; the comparison on this dimension permits some consideration of the feasibility of civilian review boards as a mechanism for police accountability.

\section{A. New York City}

The Civilian Complaint Review Board, as a citizen-dominated commission, lasted only four months between July and November Ig66. But as a part of the structure

\footnotetext{
${ }^{37} I d$.

${ }^{88}$ Brief for Plaintiff at 5, 6, Harrington v. Tate, $435 \mathrm{~Pa}$. I76, 254 A.2d 622 (I969).

${ }^{39}$ Gellhorn, supra note $2 I$, at 8.
} 
of New York City's Police Department, the CCRB has a history dating from the early $1950^{\prime}$ 's. $^{40}$ At that time a grand jury investigation of a case of alleged police brutality and other information about police misconduct created pressure for the creation of machinery for the consideration of citizens' complaints. In I953 a Civilian Complaint Review Board was established within the police department.

The Police Commissioner appointed three Deputy Commissioners to the Board. None was a member of the uniformed force and all were located administratively within the Community Relations Division. The Board's responsibility was to review reports prepared by commanding officers of the policemen whom civilians had charged with unnecessary or excessive use of force or abuse of authority. The Board conducted no hearings; the members simply recommended actions to the Police Commissioner on the basis of the reports they received. The Police Commissioner took these recommendations as advisory and was not bound by the decision of the Board.

Approximately ten years later, this arrangement was subjected to substantial criticism as civil rights and civil liberties groups became more concerned with police treatment of minority groups in general and their action during riots and demonstrations in particular. A Democratic city councilman, reacting to police conduct during a peace demonstration, introduced legislation in $I 964$ to establish a police review board outside the police department. The matter was referred to a subcommittee of the Council for study. A year later majority and minority committee reports were presented. The majority found no need to change the existing structure for review of citizen complaints against the police and concurred with the police position that an external review board would decrease department morale and efficiency.

But by the time these reports were published, the matter of civilian review had become a controversial political issue. In the Ig65 mayoral campaign, John V. Lindsay, the Republican candidate, promised that, if elected, he would change the composition and structure of the Civilian Complaint Review Board. He presented his plans for civilian review in his first major policy speech on May 2r, I965, only days after the City Council reports were made public. Hearings on the bill before the full Council generated further controversy. The Patrolmen's Benevolent Association (PBA) was able to mobilize a force of five thousand off-duty policemen to picket City Hall on June 29, during the hearings, and to collect over 500,000 signatures on petitions protesting any form of outside review.

The incumbent Police Commissioner defended the police depantment's method of handling civilian complaints at the hearings and opposed any outside review plan. His position reflected the professional view of police administration that discipline is the responsibility of the Police Commissioner and not that of the Mayor or the City Council. The Commissioner offered plans to alter some of the practices of the

to The history of civilian review in New York City follows the presentation found in E. Kaplovitz, The Civilian Review Board, May 16, 1967 (unpublished senior essay, Government, Barnard College). 
existing Civilian Complaint Review Board and eventually ordered substantial changes in the structure and operations of the Board.1 But the issue had grown beyond the question of administrative reform.

Lindsay's election determined the outcome of the civilian review issue. None of the several bills that had been introduced in the City Council were passed. The PBA remained vigorously opposed to any form of outside review, and the Police Commissioner stood firm in his opposition. What had started out as a debate within City Council had moved to the public domain during the campaign and and now became an administrative decision for the Mayor. A task force report on the police that Lindsay had commissioned recommended a civilian review board. Lindsay made his position clear; he was going to have an outside review board even if it meant a new Police Commissioner.

When the term of the incumbent Commissioner expired, the new Mayor appointed another man, Howard R. Leary, who had been Police Commissioner in Philadelphia. The rules and procedures governing civilian complaints were amended by the new Commissioner, effective June 30, I966; and the civilian-dominated CCRB was established.42 The Mayor appointed four citizens and the Commissioner appointed three high-ranking police officers.

Under the amended rules, the CCRB was authorized

to investigate and to review allegations of misconduct by members of the department involving:

a. Unnecessary or excessive use of force

b. Abuse of authority (includes unreasonable action taken in an official capacity which deprives individuals of rights guaranteed by law)

c. Discourtesy, or abusive or insulting language

d. Language, conduct, or behavior which is derogatory of a person's race, religion, creed, or national origin. ${ }^{43}$

Incidents that fell outside the jurisdiction of the CCRB, but that were still matters for police investigation, were forwarded to the Office of the Chief Inspector.

The PBA immediately announced organization of the Independent Citizens Committee Against Police Review Boards (ICC). At the same time another organization, FAIR (Federated Associations for Impartial Review), began a campaign to counter the efforts of the PBA. The PBA had not been successful in blocking the civilian-dominated review board in the courts, but it was determined to bring the issue to the voters as a referendum question. After some legal skirmishing with city officials, the question was placed on the ballot for November 1966 .

The John Birch Society, the Conservative Party, American Legion Posts, and many other groups joined the PBA and the ICC opposing civilian review. On the other side, the liberal establishment of the city was amply represented by the

\footnotetext{
${ }^{1}$ New York, N.Y., Police Dep't, General Orders No. 28, Amendments to the Rules and Procedures, Sept. I3, 1965.

${ }^{2}$ General Orders No. I4.

${ }^{18}$ Id. at 3-4.
} 
New York City American Civil Liberties Union, the American Jewiseh Committee, and the Liberal Party, in addition to FAIR. The opposing forces were not equally financed. The PBA pledged to use its entire treasury of 1.5 million dollars in the campaign, if necessary. The initial budget of the ICC was $\$ 500,000$ with $\$ 200,000$ earmarked for television and radio advertising. FAIR, on the other hand, spent less than $\$ \mathrm{r} 20,000$.

The battle over referendum votes was bitterly fought. The campaign in favor of the question (thus, opposed to civilian review) carried overtones of racial hostility and fear of an increase in crime. It was the law-abiding, white citizen who would be threatened if the police were constrained by civilian review. The result of the voting reflected these concerns. The voters supported the referendum abolishing civiliandominated police review by a margin of more than three-to-one. The issue was successful in white, middle-class neighborhoods and ethnic enclaves. The vote favoring civilian review was concentrated in black and Puerto Rican neighborhoods. ${ }^{44}$

\section{B. Philadelphia}

The Philadelphia Police Advisory Board (PAB) grew out of a strong movement for municipal government reform. After sixty-seven years of Republican control, a reform Democratic administration took office in I952. The Republican administration had been marked by allegations of corruption. As early as I904, Lincoln Steffens characterized Philadelphia as a corrupt and contented city.$^{45}$ The police were deeply entrenched in the political organization. ${ }^{46}$ District commands, for example, were allegedly often filled on the recommendation of the local party chieftain. Therefore, one of the goals of the reform movement was to rebuild the police department. Although an able new commissioner was appointed, the department could not have been expected to improve significantly in a short period of time. Even after several years of reform administration, Reichley reported that a "discouragingly large number of police are bought outright with bribes directly to the police officers involved." 47

In the late I950's the City Council's Committee on Law Enforcement and Government opened hearings to investigate alleged illegal search and seizure operations in a police department attack on numbers writing. ${ }^{48}$ Civil rights and civil liberties organizations took advantage of the opportunity afforded by the hearings to bring up other instances of police misconduct. The ACLU, for example, presented information gathered over the years concerning alleged abuses, particularly those that the organization felt had not received proper attention from the police department. ${ }^{40}$

\footnotetext{
"D. Aввотt, L. Gold, \& E. Rogowsry, Police Politics, and Race (1969).

${ }^{\iota 5}$ Steffens, Philadelphia: Corrupt and Contented, in The SHAMe of the Cirres 134 (Hill \& Wang eds. r957).

$10 \mathrm{~J}$. Reichley, The Art of Government 30 (I959).

"7 Id. at 28 .

${ }^{48}$ Coxe, supra note 16 , at 142 .

${ }^{10}$ Hudson, The Civilian Review Board Issue as Illuminated by the Philadelphia Experience, 6 CrimINOLOGICA I8 (I968).
} 
These organizations focused on the inadequacy of measures for redress of civilian grievances against the police and advocated establishment of a police review board.

Efforts by some City Councilman to secure passage of a bill creating a civilian review board were frustrated, but Mayor Richardson Dilworth, sympathetic to the idea and its supporters, used the power of his position to establish such a board. On October I, I958, he appointed five men to the Philadelphia Police Review Board. To these five men he gave the following mandate:

This Board was charged with the responsibility of considering citizens' complaints against the police where the charge involved brutality, false arrest, discrimination based upon race, religion or national origin, or other wrongful conduct of police personnel toward citizens. ${ }^{50}$

From its inception the PAB faced opposition from the Fraternal Order of Police (FOP), a benevolent association which acts as the spokesman and bargaining agent for policemen in Philadelphia. The FOP maintained continuing opposition, highlighted by two suits filed to enjoin the operation of the Board. The first, filed late in 1959, was withdrawn when the Board agreed to a few modest reforms. The second complaint, filed in 1965 , was in litigation for four years and helped to produce the Board's eventual demise.

The Board's problems were not derived solely from the opposition of the FOP. Vacancies on the Board or in the position of Executive Secretary were not always filled promptly by Mayor Tate who succeeded Mayor Dilworth. Tate was not a reformer, but a loyal member of the regular Democratic organization that had begun to replace the reformers in a number of city offices. In 1963 , he replaced the first Executive Secretary, a very outspoken liberal, with a man who was less militant. Upon the latter's resignation, the Mayor took five months to name a replacement; this resulted in a hiatus in Board activities. The next Executive Secretary, the third and last in the history of the $\mathrm{PAB}$ and a regular Democrat, proved to be very effective in the office until 1967 when the second suit brought by the FOP resulted in an injunction suspending PAB hearings. ${ }^{51}$ While it was possible to appeal that decision, the City Solicitor's Office did not move promptly. Advocates of the PAB, including the civil rights and civil liberties organizations that had been active in its creation, were dissatisfied but decided to refrain from any pressure for appeal until after the forthcoming mayoral campaign.

Like many others in the second half of the 1960 's, the 1967 election campaign in Philadelphia had a strong undercurrent of concern about white backlash and a very strong emphasis on law and order. The incumbent Mayor faced an up-hill fight. He entered as an underdog and without complete control of the local party organization. By very clever strategy he was able to gain the support of those concerned with law and order without losing the black vote. Although not a strong adovcate of

\footnotetext{
${ }^{80}$ [i959] Pa., Philadelphia Police Advisory Bd. Ann. Rep. - [hereinafter cited as i959 Ann. Rep.].

51 Harrington v. Tate, 435 Pa. 176,254 A.2d 622 (1969).
} 
civilian review, Mayor Tate had indicated his support for the PAB on several occasions. Since his opponent was also known to favor the PAB, PAB supporters decided not to politicize the issue. $A$ hardening of opposition to the $P A B$ might have forced the incumbent to side with that opposition if he had thought they held the balance in the election.

When Mayor Tate was re-elected, those who favored the PAB became impatient. The Mayor gave no indication that he was going to press for an appeal of the earlier unfavorable court decision, and the PAB remained inactive for several months. In a move calculated to force action by the Mayor or the City Solicitor's Office, members of the $\mathrm{PAB}$ retained two prominent Philadelphia attorneys to represent them in appealing the case. This action was found to violate a provision of the city charter prohibiting city employees from taking independent legal action in such cases. Nevertheless, the attempt did have the desired effect. At a Mayor's cabinet meeting in early 1969 , the decision was made to proceed with the appeal.

The Supreme Court of Pennsylvania ruled in favor of the PAB, but the Board was not reactivated. ${ }^{52}$ The Mayor, out of the country at the time of the decision, asserted in a telephone interview that there was "no reason for haste in re-activating the Police Advisory Board." $53 \mathrm{He}$ announced that upon his return he would consult with various members of his administration, and in particular with Police Commissioner Rizzo. The outcome of those consultations was obvious to most observers. The City Council President stated flatly: "If he [Tate] waits for me he will never reactivate it. I was against it at the beginning and I'm against it now." The hostility of the Police Commissioner to the PAB was already public knowledge. The Mayor announced his decision in a speech before one hundred members of the police command. In terminating the $\mathrm{PAB}$, the Mayor stated: "This is a type of a Christmas present to you gentlemen."

Political observers in Philadelphia were convinced that the Mayor was responding to the wishes of his Police Commissioner, who was gaining political power in the city. ${ }^{56}$ If politics for years had encroached upon the police organization, it now looked as though the police were encroaching upon politics. This interpretation gained further support when Commissioner Rizzo subsequently and successfully ran for Mayor of Philadelphia with the the support of Mayor Tate.

\section{Comparisons}

Both the CCRB and the PAB were products of liberal reform politics. Each was established at a time of public concern over excessive force and denial of civil rights by policemen. There were, however, some important differences. The PAB was born in a period of great sympathy for policies meant to assist minority groups. This sym-

\footnotetext{
${ }^{82} I d$.

53 The Evening Bulletin (Philadelphia), June 28, rg69, at I, col. 8.

os The Evening Bulletin (Philadelphia), July Io, 1969, at 34, col. 3.

${ }^{55}$ Philadelphia Inquirer, Dec. 13, 1969, at 1 .

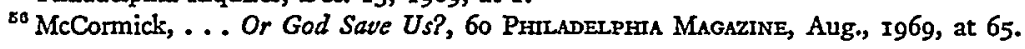


pathy began to deteriorate as the decade of the I960's progressed; urban politicians became concerned over backlash and were unwilling to be as progressive as they once were. The civilian review board in New York City was proposed when these feelings were extraordinarily intense, and the campaign waged against it exploited these feelings.

In Philadelphia, the creation of a civilian review board was one of a number of reforms introduced to improve the efficiency and responsibility of city government after more than a half century of desultory, one-party rule. To some extent, there was consensus among the public, the elected officials, and the police command that reforms were needed. The Police Commissioner, himself a reform appointee, was not publicly upset over the prospect of civilian review. Several police commissioners who served later during the PAB's history cooperated with the Board and did not publicly criticize it. Until the appointment of Commissioner Rizzo in I967, the FOP could not claim, as the PBA did in New York City, that the Mayor had disregarded the advice of a competent Police Commissioner.

In New York City, on the other hand, civilian review was introduced as a political issue in the 1965 mayoral campaign. Lindsay clearly hoped to win support from a constituency that regarded the police with mistrust. But in New York City, in contrast to Philadelphia, the issue divided those who carried the responsibility for law enforcement. On one side were the police themselves, the command structure, and the mutual aid organization, the PBA. On the other side was a man who, first as a candidate and then as Mayor, doubted the police department's ability to redress citizen grievances.

Just as similar considerations lay behind the appointments of these two Boards, the political decisions which brought their defeats were based upon similar sentiments. The opposition in both cities was a well-mobilized interest group. The associations of policemen were deeply concerned and threatened by civilian review of the police. The $\mathrm{PAB}$ was a constant source of irritation for the Philadelphia policeman. It never lost its importance as an occupational problem.

Supporters of civilian review were never as single-minded in their dedication to maintaining it as the police were to defeating it. The review board issue was one among many that occupied public interest and resources. But even more importantly, those who would benefit most from civilian review were a very fragmented constituency. It is harder to form an alliance among those with a potential problem than it is among those facing an immediate threat.

\section{III}

\section{The Structure and Operations of Two Crvilian Review Boards}

The previous sections have raised the general issue of accountability of public bureaucracies, discussed how this issue has been debated with regard to police review boards, and reviewed the political history of two boards. Attention is now directed toward the functioning of these two boards, the New York City Civilian 
Complaint Review Board, when it was dominated by civilians, and the Philadelphia Police Advisory Board. The first three parts of the section will present details about the boards-their structures, operations, actions and recommendations, and a portrait of the complaints. A final part summarizes selected comparisons between them and highlights problems inherent in civilian review as a means of insuring accountability.

\section{A. Operations}

\section{r. New York City}

The CCRB operated according to orders of the Police Commissioner specifying its function, rules, and procedures. ${ }^{57} \mathrm{An}$ administrative staff of civilians and an investigating unit of police officers carried on the day-to-day work of the Board. Heading this staff were civilian appointees of the Police Commissioner to the offices of Executive Director and Assistant Director. The Assistant Director was in charge of conciliation procedures; the civilian staff included two hearing officers. A member of the police force above the rank of captain was assigned to direct the activities of the full-time investigating unit. The chief task of the seven-member Board itself was to review investigations and hearing records and to decide whether to recommend to the Commissioner that departmental charges be preferred against an officer. Board members appointed by the Mayor received fifty dollars for each hearing or meeting attended. ${ }^{\mathbf{5}}$

The Commissioner's order stated that: "Complaints may be filed by any interested person or group. Complaints shall be accepted in writing, in person, or by telephone, whether or not the complainant offers his name." ${ }^{\text {"Ig }}$ The CCRB's machinery was set in motion on receipt of a complaint, either directly as presented by the complainant or as transmitted by any member of the department. Once the CCRB had received a complaint and determined that it fell within the jurisdiction of the Board, the staff would proceed in one of two ways. If the Assistant Director decided that the incident could be settled by conciliation, this approach was pursued. If such a settlement was not possible, the staff of police officers assigned to the CCRB began an investigation of the incident. When an investigation was completed and returned to the administrative staff, the Board determined whether a hearing should be held and whether the Board should be represented at that hearing. Under the rules, a hearing was to be held within twenty days after receipt of the investigation report. Both the complainant and the accused policeman were to be informed of the time and place of the hearing. Hearings could not take place at a station house. ${ }^{60}$ All parties were to be notified that they could be represented by counsel. If financial

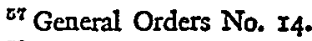

${ }^{88}$ Id. at 3 .

${ }^{60}$ Id. at 6.

${ }^{00}$ Id. at 15.
} 
problems prevented either a complainant or a policeman from hiring an attorney, the Board was instructed to find suitable counsel at no expense to the Board. ${ }^{01}$

Hearings were conducted by a hearing officer. When Board members were designated to represent the Board, they were to be an odd-numbered panel of one to seven individuals with the stipulation that the "majority of each panel shall consist of members appointed by the Mayor, ${ }^{362}$ that is, civilian members. Hearings were not open to the public; but they were open to complainants, the accused, and a limited number of individuals representing them. ${ }^{63}$ The Board had access to subpoena power through the Police Commissioner, which could be used "to compel the attendance at a hearing of witnesses or the production of evidence." ${ }^{14}$ Requests for issuance of a subpoena could be made on the hearing officer's approval by any member of the CCRB representing it at a hearing, by the hearing officer, or by a complainant or a policeman against whom a complaint had been made. ${ }^{05}$ Formal rules of evidence did not apply; the hearing officer was empowered to rule on the relevancy of questions. Transcripts of hearings were made available at cost to the principal parties.

\section{Philadelphia}

In contrast to the highly bureaucratic methods of handling citizen complaints in New York City, the Philadelphia Police Advisory Board followed a less structured format. The Board, originally composed of five members, was later expanded to eight positions. Members served without compensation. ${ }^{66}$ The Mayor of Philadelphia made appointments to the Board and gave it his mandate, but he did not prescribe any rules, regulations, or procedures. Initially, there was neither a budget nor provision for office space or secretarial and administrative assistance. As the work load of the PAB increased, a part-time Executive Secretary was hired. ${ }^{67}$ Subsequently, the position was made full-time, and the Board was given clerical help and office space. ${ }^{68}$ In the last full year of its operation, 1966 , the Board was allocated $\$ 17,000$ from the city budget to cover salaries and expenses.

The generality of their duties, combined with the absence of well-defined rules and procedures, made the Board proceed cautiously in its initial work. The records suggest, and those close to the Board at that time confirm, that the members were careful to specify the scope of jurisdiction and rules of operation within the limitations imposed by the Mayor's authorization and their lack of resources. In its initial cases, the PAB determined on an individual basis how they would be handled.

\footnotetext{
${ }^{61}$ Id. at 17 .

${ }^{62} \mathrm{Id}$. at 16.

${ }^{83} \mathrm{Id}$. at I7.

${ }^{34} I d$. at $\mathrm{x} 6$.

${ }^{\circ 5} \mathrm{Id}$.

${ }^{60}$ I962 ANN. ReP. at I.

of [rg60] PA., Phalldelpha Police Advisory Bd. ANN, Rep. 8.

${ }^{68}$ [1963] PA., Philadelphin Police Advisory Bd. AnN. Rep. I [hereinafter cited as Ig63 ANN.
} REP.]. 
By the end of the first year, however, it had adopted a standard set of rules and procedures. $^{68}$ The initial codification was done by an attorney on the Board with the assistance of an interested law student; it served with some modifications for as long as the Board existed. ${ }^{70}$ It is important to note that in contrast to those in New York City, the rules of the PAB lacked the advantage, insofar as the police department was concerned, of having been issued as a directive from the Police Commissioner.

The regulations and procedures conveyed the Mayor's mandate to investigate police misconduct. "The term 'miscon'duct' shall include, but not be limited to, mistreatment, abusive language, false arrest, unreasonable or unwarranted use of force, unreasonable search and seizures, denial of civil rights or discrimination because of race or religion or national origin." ${ }^{11}$ Cases were accepted from individuals only-no groups or organizations could file complaints, as they could in New York City-nor could the complainant remain anonymous. A case would be terminated if the complainant decided to withdraw the complaint. The rules stated that, with some exceptions, a complaint must be filed within ninety days of the alleged incident.

Because the PAB had no investigating staff, it utilized the Philadelphia Police Department Community Relations Unit for investigating incidents. This arrangement severely limited the effectiveness of the $\mathrm{PAB}$ since the quality and promptness of the investigations varied widely. ${ }^{\mathbf{7 2}}$ No power of subpoena was granted the PAB, either directly or indirectly. Once an investigation had been completed, the PAB determined whether a public hearing was warranted. Even if the PAB concluded that a hearing was unnecessary, the complainant could request one. ${ }^{\mathbf{7 3}}$

Although informal settlements were not mentioned in the rules, the Executive Secretary developed a number of settlement arrangements as alternatives to a formal investigation and hearing. These included explaining police actions to citizens, obtaining a letter of apology from either the officer involved or the Community Relations Unit of the Police Department, informing the complainant that his case lacked substance, expungement of the complainant's police record, or holding a conference among the contending parties. ${ }^{74}$ The administrative strategies for settlement became an issue between Board members and the Executive Secretary because the Board believed that the Executive Secretary sometimes acted beyond his authority. A revision of the rules clarified the situation, giving the Board final jurisdiction over case settlement. ${ }^{75}$ Some cases became moot when the Police Commissioner, on

\footnotetext{
${ }^{\circ 0}$ Coxe, supra note 16 , at 145 .

70 1959 ANN. Rep. at 2-4; 1963 ANn. Rep. at exhibit B.

${ }^{71}$ Philadelphia, Pa., The Police Review Board, Regulations and Procedures, Sept. I5, I959, at 1. Note that the name "Police Review Board" was changed to "Police Advisory Board" in Ig6o.

${ }^{72}$ Hudson, supra note 49 , at 24 .

${ }^{78} 1963$ ANN. REP., at exhibit B.

"Hudson, Organizational Aspects of Internal and External Review of the Police, J. CRIM. I.C. \& P.S. (forthcoming).

${ }^{75}$ [1964] Pa., Phunabelphia Police Advisorx Bd. AnN. Rep., exhibit A, at 2.
} 
hearing of an incident, took direct action either before the investigation was completed or before the PAB held a hearing.

Hearings were conducted by a panel of Board members; a minimum of three was required. ${ }^{76}$ No formal records or transcripts of these hearings were kept. Witnesses, police officers, and complainants testified under oath and were subject to cross-examination. The rules of evidence did not apply at hearings. Each side had the right to counsel, but in practice, policemen were usually represented by the Fraternal Order of Police, and citizens had no representation. The PAB recognized that this posed a problem. It stated in its Fifth Annual Report that "when a complainant is unrepresented by counsel, and the Board must consequently play an active role in developing the complainant's case, the appearance of impartiality is impaired, and police respect for the Board is weakened."77 To eliminate this weakness, a group of lawyers was recruited to be available to represent $\mathrm{PAB}$ complainants on a voluntary basis.

\section{B. Actions Based on Hearings}

Upon completion of a hearing in New York City, the various documents were reviewed by the Board in order to ascertain whether a recommendation should be made to the Police Commissioner. A recommendation specified only that it was the opinion of the CCRB that charges should be preferred against the offending officer. "The recommendations of the Board shall be advisory only and shall in no way limit the authority of the Police Commissioner to dispense discipline within the department."78 As in other disciplinary cases, the Police Commissioner had at his disposal machinery for departmental hearings to consider the evidence for disciplinary action against the police officers.

No notation of CCRB proceedings was to appear in the official file of any police officer involved. This was true whether or not the Board recommended that the Police Commissioner act on the complaint. ${ }^{78}$ Notice of disposition of a complaint by the Police Commissioner was sent by registered mail to both complainants and police officers. ${ }^{80}$ When charges were preferred, however, there was no provision for informing the complainant of the final outcome of any disciplinary action.

Unlike the $C C R B$, the $P A B$ did recommend specific disciplinary action, including reprimand, suspension, or dismissal. ${ }^{81}$ Occasionally, the Board recommended commendation of the officer for his performance during an incident. All recommendations were strictly advisory to the Police Commissioner, who had final authority in disciplinary matters. In almost all cases, however, the PAB's recommendations apparently were followed. The complainant, but not the policeman,

\footnotetext{
${ }^{78}$ Id., exhibit $A$, at 4 .

77 I963 ANN. REp. at 2.

${ }^{78}$ General Orders No. I4 at r8-rg.

ro Id. at I9.

${ }^{80} \mathrm{Id}$.

${ }^{81}$ Hudson, supra note 49 , at 25.
} 
was sent a letter stating the Board's recommendation. Neither the PAB nor the complainant was informed of disciplinary action taken by the Commissioner.

Aside from recommendations for disciplining a police officer, the most controversial recommendations from the $\mathrm{PAB}$ were for expungement of police department arrest, fingerprint, or photograph records in cases where charges had later been dropped. From the point of view of a citizen, the existence of an unjustified arrest record is particularly damaging and embarrassing. Therefore, the complainant often was more interested in clearing his own name than in causing any sanction against the arresting officer. There is some question, however, whether records can properly be removed without a judicial order. ${ }^{82}$

\section{Complainants and Complaints}

Data on characteristics of complainants to the boards in New York City and Philadelphia also provide some interesting comparisons. Since the CCRB existed for only four months, caution is required in interpreting these data. During the period of the CCRB's operation, the poor did not utilize it to the extent expected. ${ }^{83}$ Nevertheless, it appears that in both New York and Philadelphia civilian review was used by members of minority groups. In both cities, non-whites were complainants more often than whites (Table I). Other data from Philadelphia indicate that complainants came from the lower socio-economic strata of the population. ${ }^{84}$ The bulk of complainants in both cities were male. Black reports that in New York City males outnumbered females as complainants by a ratio of two to one; in Philadelphia, the ratio was almost three to one. ${ }^{85}$

While no comparative data are available on arrest records of complainants, the Philadelphia files reveal that about one-third of those initiating proceedings in that city had previous police records. However, only about eight per cent of all complainants had ever been convicted of a felony. These data tend to refute the claim that civilian review boards will be used mainly by habitual criminals.

In both cities unnecessary force was the most frequently alleged abuse (Table II). The next most frequent complaint in New York City was discourtesy, and in Philadelphia it was harassment. Abuse of authority in one form or another was the third-ranked complaint.

In the four months the CCRB operated under civilian domination, approximately $44^{\circ}$ complaints were filed with it. Of these, half were not processed before the referendum removed the civilian members. The balance were disposed of as follows: Io cases were outside the CCRB's jurisdiction and were referred elsewhere; 55 cases were successfully conciliated; IIo complaints were found to be unsubstantiated; 5

\footnotetext{
${ }^{82}$ Harrington v. Tate, $435 \mathrm{~Pa} .176,254$ A.2d 622 (I969).

${ }^{83}$ N.Y. 'Times, Oct. 21, I966, at I, col. 7 .

8t Hudson, supra note 49 , at 21.

${ }^{85}$ Black, supra note 26 , at Ior.
} 


\section{TABLE I}

Race of Civilian Review Board Complatnants

\begin{tabular}{|c|c|c|}
\hline & New York Citya & Philadelphisb \\
\hline 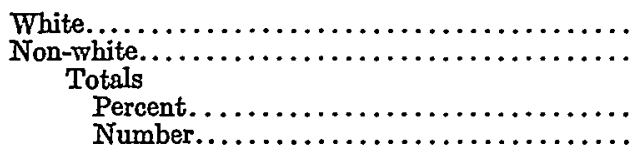 & $\begin{array}{l}49 \% \\
51 \\
100 \% \\
442\end{array}$ & $\begin{array}{l}28 \% \\
72 \% \\
100 \% \\
868\end{array}$ \\
\hline
\end{tabular}

aComputed from data in A. Brack, The Peopes and THe Poltce, Appendix III (1968) for tho four months the CCRB was civilian-dominated.

based upon principal complainants for all incidents from 1958-1967.

TABLE II

Allegations Against Police Officers in New York City and Philadelphia

\begin{tabular}{|c|c|c|c|}
\hline \multicolumn{2}{|l|}{ New York Citya } & \multicolumn{2}{|c|}{ Philadelphiab } \\
\hline 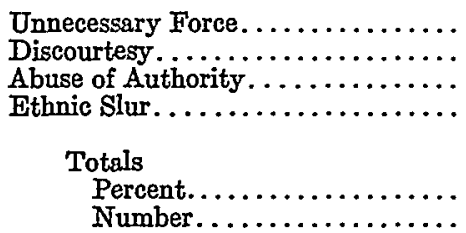 & $\begin{array}{l}52 \% \\
23 \\
20 \\
5 \\
\\
100 \% \\
442 \%\end{array}$ & $\begin{array}{l}\text { Brutality } \\
\text { Harassment } \\
\text { Mllegal Search and Seizure } \\
\text { Other }\end{array}$ & $\begin{array}{l}45 \% \\
21 \\
15 \\
19 \\
100 \% \\
868\end{array}$ \\
\hline
\end{tabular}

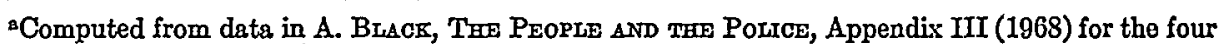
months the CCRB was civilian dominated.

Based upon principal complainants for all incidents from 1958-1967.

cases were sent to the Police Commissioner for action; and the remainder were either still under investigation or awaiting review of the board. ${ }^{86}$

Table III indicates the resolution of $\mathrm{PAB}$ complaints. Hearings were conducted for $16 \%$ of all cases, and of these approximately $35 \%$ resulted in recommendations of discipline of the police officers. Informal settlements were employed in $20 \%$ of the total cases. In $3 x \%$ of all cases some resolution occurred, either disciplinary recommendations, disciplinary action on the part of the police department, or informal settlements. It appears, then, that the PAB had an active role in the resolution of a number of police-citizen altercations.

\section{Legitimacy}

Several additional comparisons between Philadelphia and New York City deserve particular emphasis. The organizational differences between the PAB and the $\mathrm{CCRB}$, when it operated as a civilian review board, led to critical differences in their activities and their image of legitimacy in the eyes of the police and the public. Similarly, the defeat of civilian-dominated review systems left differing forms of

\footnotetext{
${ }^{86}$ Interview with Algernon D. Black, former Chairman, N.Y.C. C.C.R.B., October 22, I97x.
} 
TABLE III

Resoldtion of Complaints Brought to the PAB: I958-1967

\begin{tabular}{|c|c|}
\hline 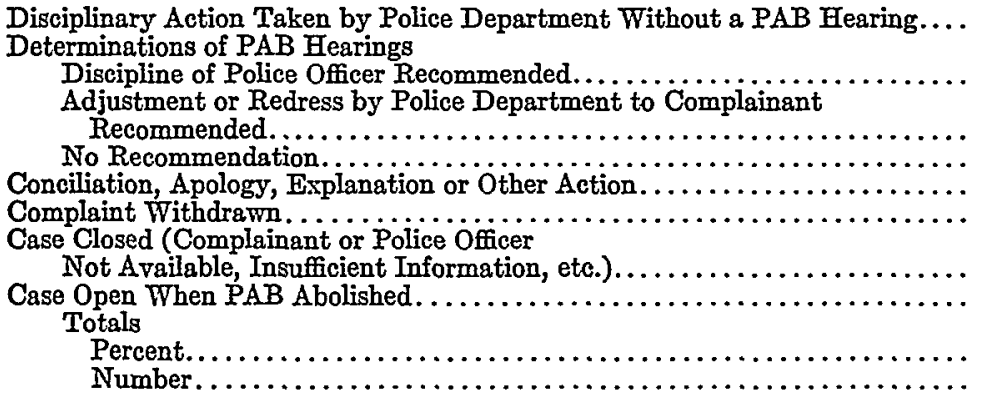 & $\begin{array}{c}2 \% \\
6 \\
3 \\
7 \\
20 \\
12 \\
33 \\
17 \\
100 \% \\
868\end{array}$ \\
\hline
\end{tabular}

official machinery for discovery and resolution of citizen complaints against the police.

In New York City the CCRB was created by shifting some authority from police personnel to civilians within the existing structure for handling civilian complaints. When the CCRB was defeated by the referendum, the changes in organization were slight; the police simply regained control of the CCRB. ${ }^{87}$

The CCRB, both during civilian domination and afteward, employed the entire police organization for its intake apparatus. A directive prepared by the Commissioner detailed the manner in which complaints were to be allocated between the units having authority to investigate them. The purpose of the order was to insure that every member of the department appreciated his obligation to forward the complaint to the appropriate unit. Under these rules, there was no characteristic of a complaint that would justify a refusal to accept it. By checking with all units having investigative jurisdiction, e.g., the CCRB and the Chief Inspector's Office, the police command could ascertain the number of complaints made, the matters complained of, the findings of the investigators, the manner of settlement, and any other information based on intake forms and other case records.

The CCRB had a large staff and an investigating unit specifically assigned to it; this provided good organizational conditions for investigating all complaints in a professional manner and for completing all work on a given complaint in a reasonably short time. In addition, two provisions of the rules helped to protect an accused officer from damaging publicity or records, while allowing the department to check the validity of a complaint. Under the rules, hearings were not open to the public, and no mention of CCRB proceedings appeared in a policeman's official file.

The organizational characteristics of the CCRB had specific effects on the accountability of the New York City Police Department to its citizens. At no time,

\footnotetext{
${ }^{87}$ N.Y. Times, Nov. 23 , I966, at I, col. 5 .
} 
including the period in which the CCRB was civilian-dominated, was the Board external to the police department organization. Thus, a citizen desiring to complain had to be willing to report to a branch of the department itself. Although members of the New York City Police Department are required by the regulations of the department to accept all citizen complaints, the extent to which this directive is evaded cannot be determined. The skeptical citizen is not likely to accept the assurances of the police command as to the accessibility of the system. There continues to be no alternative, external police review system to receive complaints from individuals who prefer to avoid dealing directly with the police organization. Had civilian domination endured, the Mayor's appointees might have been able to correct any tendency toward bias in the investigations, to prevent superficial evaluations by the Board, or to insure that Board findings were not ignored after they were forwarded to the Police Commissioner.

As a result of the demise of civilian-dominated review, the police department as an organization has essentially the same information about civilian complaints that it had previously. Assuming that departmental decisions were not affected by the presence of Board members appointed by the Mayor-something we cannot judge -the main difference for the department between a civilian-dominated and policedominated CCRB may be the degree of confidence which citizens have in the review system. Thus, some complaints which might have been taken to the civilian Board may now be withheld because of distrust of the present Board. In addition, citizens at large may have had more confidence in the whole department because of the presence of civilians on the Board:

It may not be incidental that the campaign for civilian review coincided with departmental efforts to improve the system for processing civilian complaints. The internal system of the department, which in design is a well-structured, comprehensive model, may be in part the result of pressures generated by the civilian review issue. The relationship cannot be established with certainty, however, and perception of it depends in part upon one's ideological position. On the other hand, some might argue that the modifications produced no improvement in the system because they operate to deflect justified criticism and thereby dilute the movement toward outside review. At the other extreme, it might be suggested that the modifications were ill-conceived because they draw valuable resources from the law-enforcement function of the department.

In Philadelphia, the PAB was created as a totally new and separate organization attached to the Mayor as chief executive of the city government and tied organizationally to the police department only indirectly through the Mayor. Although there was no formal connection between the PAB and the Philadelphia Police Department, informal and indirect relationships did exist. For example, the PAB was provided no source of investigations other than the department. Most complaints, therefore, were sent routinely to the Community Relations Unit for investigation. In order 
to achieve informal settlement of complaints, it was usually necessary for the PAB to deal with police officers, including those who had been accused and others in the command structure or in special units. Finally, if a PAB hearing resulted in disciplinary recommendations, the matter would be forwarded through the Mayor to the Police Commissioner for his consideration.

A citizen with a complaint against a policeman could have reported it to the department directly, either to central headquarters or at a local precinct house. Philadelphia Police Department records of disciplinary cases show that between $\mathrm{I} g 60$ and 1968 some officers were charged and found guilty of infractions of departmental rules on the basis of citizen complaints. ${ }^{88}$ There was, however, no arrangement in Philadelphia which paralleled the New York City requirement that complaints be received and forwarded by all members of the department. The normal response of any bureaucrat is to handle matters for which he has been given instructions and to avoid those which have not been defined by the organization as within its jurisdiction. Therefore, many complaints that were processed in New York would probably not have been accepted by individual members of the Philadelphia Police Department because the manner for dealing with them had not been defined. This is most likely the case with respect to complaints which in New York might have been settled by conciliation between police officer and citizen-those that did not appear to involve violation of the departmental rules. As we have noted, complaints of the latter sort have been handled in Philadelphia, but have processed through the formal departmental disciplinary channels. This departmental procedure presumably has continued in the absence of the PAB.

The Philadelphia experience with the PAB suggests a number of considerations relevant to the issue of police accountability in that city. In the PAB, Philadelphia did have an external police review board which accepted and settled citizen complaints. Its public image of legitimacy was marred, however, by inadequate staffing, the most serious consequence of which was the absence of an investigating staff independent of the police department. The Board's legitimacy in the eyes of the Department, on the other hand, was undermined by the fact that the Board's position was external to the Department in that it was not subject to procedures promulgated by the Police Commissioner. Specifically, officers felt threatened by public hearings and suspected that being the subject of a PAB complaint was harmful to one's career in the department. There was no guarantee that the result of PAB proceedings would not be entered in an officer's personnel file. Even if these particular matters had been adjusted to provide greater protection to the individual officer, the basic distrust of external review would have remained an issue for most members of the department.

The demise of the PAB left Philadelphia with no official organization, internal or external to the police department, specifically directed either to receive and

\footnotetext{
${ }^{88}$ Hudson, supra note 74.
} 
investigate civilian complaints against the police, or to advise the Commissioner as to which complaints justify initiation of internal disciplinary proceedings. The function of the PAB in these areas has not been taken over by any one organization, although it is likely that some complaints are now being handled satisfactorily by the Mayor's Office of Information and Complaints, the Human Relations Commission, and units of the police department. As a result, it is particularly difficult to know what complaints citizens have and what is being done about them.

There is no sign that the existence of the PAB or the protracted debate over its desirability produced any reaction within the Philadelphia Police Department leading to improvement of either its procedures for handling civilian complaints or policecommunity relations in general. Rank-and-file opposition to the PAB and, in recent years, outspoken opposition from the top command, may have channeled energies away from any effort to make organizational adjustments which would have increased the responsiveness of the department. The general level of publicity surrounding the police review issue and particular investigations by the PAB may have heightened the department's awareness of citizens' concern, particularly at the command level. It cannot be documented, however, that this resulted in any substantial modification of departmental practices.

\section{CONCLUSION}

As pointed out in the introduction to this paper, the need for accountability is not unique to police departments. But the recent efforts to establish efficient and responsive police review boards in New York and Philadelphia bring into focus the underlying problems facing any institution which makes such an attempt. Chief among these problems is the diffculty of establishing a review mechanism which will be acceptable to both the community and the professionals involved. The twopronged dilemma of legitimacy is rooted in the juxtaposition of beliefs held by the officers-who feel they are being betrayed when operations are scrutinized by outsiders-and the citizens-who contend that the solidarity of the force effectively precludes redress. Inducing confidence among the constituents in the system for adjudication of grievances, while maintaining the trust and good will of the professionals, requires in the monitoring mechanism a delicate balance between suitable impartiality toward the force and understanding of the policeman's difficult task.

The relative lack of success by New York and Philadelphia in creating an enduring review board previews the problems facing future endeavors to provide channels of redress for citizens who feel their rights have been violated by a public service agency. These problems can only be magnified during the delay since polarization between citizens and service groups becomes more severe with time. 